\title{
PENGEMBANGAN KAWASAN PESANTREN MODERN RAUDHATUL ULUM MERANTI
}

\author{
Sariman ${ }^{1}$, Zairin Zain ${ }^{2}$, M. Ridha Alhamdani ${ }^{3}$, Hamdil Khaliesh ${ }^{4}$, Jawas Dwijo Putro ${ }^{5}$ \\ ${ }^{1}$ Mahasiswa, Program Studi Arsitektur, Fakultas Teknik, Universitas Tanjungpura. \\ sarimanarjun@gmail.com \\ 2,3,4,5 Program Studi Arsitektur, Fakultas Teknik, Universitas Tanjungpura
}

Naskah diajukan pada: 25 Desember 2020

Naskah revisi akhir diterima pada: 28 Desember 2020

\begin{abstract}
Abstrak
Pondok Pesantren Raudhatul Ulum Meranti merupakan Lembaga dakwah yang didirikan untuk mencerdaskan generasi Islam di Indonesia, khususnya di Kalimantan Barat. Pesantren Raudhatul Ulum Meranti berdiri sejak tahun 1896 di sebuah perkampungan yang bernama kampung Meranti, Kecamatan Sungai Ambawang, Kabupaten Kubu Raya. Kurikulum yang diterapkan pesantren tersebut awalnya hanya menganut sistem klasik (pengajaran kitab kuning) berkembang menjadi kurikulum yang bersumber dari Kementerian Agama (KEMENAG). Tujuan dari pengembangan kawasan Pesantren Raudhatul Ulum Meranti dapat membuat fasilitas-fasilitas yang sesuai dengan sistem pendidikan modern. Lokasi perancangan berada di Jalan Muhajirin, Kampung Meranti, Desa Puguk, Kecamatan Sungai Ambawang, Kabupaten Kubu Raya. Metode tahapan pada perancangan ini dimulai dari Tahap Gagasan, Pengumpulan Data, Analisis, Sintesis, Pra Rancangan dan Tahap Pengembangan Rancangan. Konsep Natural Pro Rate diterapkan agar kawasan yang masih hijau tidak harus membangun dengan merusak alam pada kawasan, melainkan menata dan menjaga kondisi alam agar tetap hijau. Hasil dari perancangan pengembangan pada Pesantren Raudhatul Ulum Meranti dapat menjadikan bangunan Masjid sebagai jantung kawasan. Fasilitas ibadah dan pendidikan dibuat bernuansa Islami dengan cara mengkombinasikan ornamen pada bangunan serta menjadikan kawasan yang terpisah antara area santri putra dan putri.
\end{abstract}

Kata-kata Kunci: Pendidikan Islam, Pondok Pesantren, Natural Pro Rate

\begin{abstract}
Raudhatul Ulum Meranti Islamic Boarding School is a da'wah institution that was established to educate the generation of Muslims in Indonesia, especially in West Kalimantan. Raudhatul Ulum Meranti Islamic Boarding School was founded in 1896 in a village called Meranti Village, Sungai Ambawang District, Kubu Raya Regency. The curriculum applied by the pesantren initially only adhered to the classical system (teaching the yellow book) and developed into a curriculum sourced from the Ministry of Religion (KEMENAG). The aim of developing the area of Raudhatul Ulum Meranti Islamic Boarding School is to make facilities suitable for the modern education system. The design location is on Jalan Muhajirin, Kampung Meranti, Puguk Village, Sungai Ambawang District, Kubu Raya Regency. The stage method in this design starts from the Idea Stage, Data Collection, Analysis, Synthesis, Pre-Design and Design Development. The concept of Natural Pro Rate is applied so the areas that are still green do not have to build by destroying nature in the area, but rather organize and maintain the natural conditions in order to remain green. The results of the development design at Raudhatul Ulum Meranti Islamic Boarding School can make the mosque building as the heart of the area. Worship and educational facilities are made with Islamic nuances by combining ornaments in the building and creating a separate area between the male and female students.
\end{abstract}

Keywords: Islamic Education, Boarding School, Natural Pro Rate 


\section{Pendahuluan}

Pondok Pesantren Raudhatul Ulum Meranti merupakan Lembaga dakwah yang didirikan untuk mencerdaskan generasi umat Islam di Indonesia khususnya di Kalimantan Barat. Pesantren Raudhatul Ulum Meranti berdiri sejak tahun 1896 disebuah perkampungan yang bernama Kampung Meranti, Kecamatan Sungai Ambawang, Kabupaten Kubu Raya. Kurikulum pembelajaran masih menganut pendidikan tradisional yang disebut sistem klasik (pengajaran kitab kuning). Pesantren Raudhatul Ulum Meranti terpecah menjadi dua Lembaga yaitu Pendidikan Islam Raudhatul Ulum 1 Meranti dan Pondok Pesantren Raudhatul Ulum Meranti. Alasan terpecahnya Pondok Pesantren tersebut dikarenakan adanya selisih paham antara ketua Yayasan dan pengasuh Pondok Pesantren, sehingga pengasuh Pondok Pesantren memutuskan untuk berpindah dan membangun Pesantren baru.

Pesantren baru didirikan pada tahun 2006 dengan nama Pondok Pesantren Raudhatul Ulum Meranti. Kurikulum yang diterapkan Pesantren tersebut awalnya hanya menganut sistem klasik (pengajaran kitab kuning) berkembang menjadi kurikulum yang bersumber dari Kementerian Agama (KEMENAG). Pendidikan yang diterapkan hanya menganut sistem tradisional (mengajarkan tentang ilmu agama Islam) dikombinasikan menjadi pendidikan modern (mengajarkan pelajaran agama Islam dan umum). Fasilitas pendidikan pada sebelumnya diperlukan adanya pengembangan untuk menunjang kegiatan belajar-mengajar di Pesantren. Keadaan fasilitas pendidikan yang kurang memadai dan tidak tertata dengan baik perlu adanya upaya dalam pengembangan kawasan Pesantren Raudhatul Ulum Meranti. Pengembangan kawasan tersebut juga berdasarkan adanya peningkatan jumlah santri dari tahun-ketahun, pada awalnya yang berjumlah 50 santri menjadi 373 santri saat ini. Jumlah tersebut tergolong dari jenjang MTs dan MA dengan jarak 9 tahun dari awal berdirinya pesantren pada tahun 2006 sampai tahun 2017.

Pihak Pesantren Raudhatul Ulum Meranti (Kyai maupun Ustadz), mengalami kesulitan dalam mengembangkan kawasan Pesantren dikarenakan minimnya keuangan yang dimiliki. Pihak Pesantren berupaya untuk menciptakan ruang fasilitas ekonomi yang berupa Ruko/Retail untuk disewakan pada masyarakat sekitar Pesantren. Tempat penyewaan dibuat untuk meningkatkan perekonomian Kampung Meranti sebagai sumber pendapatan Pesantren. Oleh karena itu, diperlukan sebuah perancangan pengembangan kawasan Pondok Pesantren Raudhatul Ulum Meranti dengan menyediakan ruang fasilitas pendidikan dan penunjang perekonomian Pesantren.

\section{Kajian Pustaka}

Menurut Ziemek (1983:16), istilah "pondok" berasal dari bahasa arab yaitu "funduq" yang mempunyai arti rumah, penginapan/hotel, juga diartikan sebagai kamar gubug dan rumah kecil dipakai dalam bahasa Indonesia dengan penekanan kesederhanaan bangunan. Adapun menurut Dhofier (1994:7) istilah pesantren berasal dari kata "santri" dengan awalan "pe" di depan dan akhiran "an" berarti guru mengaji. Jadi, Pondok Pesantren adalah sebuah Asrama pendidikan Islam tradisional di mana para siswanya tinggal bersama dan belajar di bawah bimbingan seseorang yang lebih dikenal dengan sebutan Kyai.

Menurut Mas'ud (2002:4), sejarah berdirinya Pondok Pesantren berawal dari adanya seorang Kyai disuatu tempat, kemudian didatangi santri yang ingin belajar agama kepadanya. Para santri tersebut mendirikan pondok-pondok di sekeliling rumah Kyai dengan maksud ingin belajar ilmu agama kepada Kyai tersebut. Maka muncullah istilah Pondok Pesantren yang semakin berkembang seiring dengan bertambahnya santri yang ingin belajar ilmu agama.

Hasil Penelitian oleh LP3S Jakarta dalam Nawawi (2006:2), pesantren yang ada di Indonesia terdiri dari 5 (lima) macam jenis dan pola fisik yaitu Pesantren Tradisional, terdiri dari bangunan Masjid dan rumah Kiai; Pesantren Semi-Tradisional, terdiri dari bangunan Masjid, rumah kiai dan asrama sebagai tempat tinggal santri yang datang dari daerah jauh; Pesantren Modern, penerapan 
kurikulum pendidikan formal dan informal seperti madrasah yang terdiri dari bangunan Masjid, rumah Kiai dan Asrama; Pesantren Komprehensip, penerapan pendidikan keterampilan seperti: peternakan, perkebunan dan lain sebagainya guna proses perkembangan santri keseluruhan; Pesantren Pembangunan, terdiri dari bangunan-bangunan pendukung seperti perpustakaan, dapur umum, ruang makan, kantor administrasi, toko dan lain sebagainya.

Menurut Ariandy dan Desty (2011:5), pesantren tradisional merupakan sistem pendidikan yang mempertahankan materi pelajaran bersumber dari kitab-kitab Islam klasik. Selain itu, pada waktu tertentu, madrasah mempraktikkan sistem khusus, seperti sorogan, untuk kemudahan pelaksanaan sendi utama. Pesantren yang menerapkan pendidikan salafi tidak mengajarkan pengetahuan non agama. Istilah salafi atau tradisional menggambarkan keadaan sebaliknya, yakni keterbelakangan, terbelenggu dengan ikatan tradisi kuno statis, sukar dan enggan mengikuti perubahan sesuai dengan perkembangan zaman. Dalam kaitan ini memang banyak orang menyangka pesantren adalah sarang kekolotan, pesantren adalah sarang konservatisme dan merek-merek keterbelakangan lain.

Menurut Setyowati (2010:4), Pondok Pesantren Modern merupakan suatu lembaga pendidikan yang mengajarkan pendidikan agama, pengetahuan umum dan juga ketrampilan serta penguasaan bahasa asing untuk menghadapi tuntutan jaman. Pondok pesantren berwawasan lingkungan ini kurikulum yang dipakai adalah perpaduan antara Depag, Depdiknas, pesantren itu sendiri dan ditambah dengan pengetahuan mengenai lingkungan hidup. Kurikulum yang ada akan dikembangkan menjadi sebuah pembelajaran yang aktif, kreatif, efektif, dan menyenangkan.

Menurut Mastuhu (1994:18), pelaku dan aktivitas di pondok pesantren modern dalam sistem pendidikan pondok pesantren terdiri dari seorang Kyai, Ustadz atau Guru, santri atau siswa dan pengurus pondok. Kyai merupakan orang yang mempunyai ilmu pengetahuan mendalam tentang agama Islam. Peranan Kyai dalam Pondok Pesantren modern adalah sebagai tempat untuk mengembalikan permasalahan serta sebagai direktur yang bertanggung jawab mengelola pondok. Ustadz bertugas membantu Kyai yang mengajar pendidikan agama, sedangkan Guru sebagai pengajar di bidang pendidikan umum. Santri adalah sebutan bagi seseorang yang mengikuti pendidikan agama Islam dan dijadikan anak didik di Pondok Pesantren. Pengurus adalah sekelompok orang yang bertugas mengurus segala sesuatu yang berkaitan dengan kegiatan maupun aktivitas yang terdapat didalam Pondok Pesantren.

Jenjang pendidikan pada Pondok Pesantren Raudhatul Ulum Meranti ini diperuntukan pada anak usia 12-15 dan 16-19 tahun dengan jenjang pendidikan Madrasah Tsanawiyah (MTs) dan Madrasah Aliyah (MA) yang ditempuh selama (3tahun-6tahun) dalam pengajarannya. Jenis Pondok Pesantren ini merupakan pesantren modern yang mempelajari ilmu agama Islam dan pendidikan umum (Rusdi, 2017).

\section{Metode}

Metode perancangan pada Pondok Pesantren Raudhatul Ulum Meranti berdasarkan permasalahan dan memadukan dengan kompleksitas literasi yang dibutuhkan. Metode yang digunakan pada perancangan Persantren tersebut adalah Natural Pro Rate (dekat dengan alam) yang berarti sebuah perancangan dapat mengekspresikan desain alami dan lingkungan yang terjaga. Ide dasar perancangan pondok Pesantren menurut Dzulfikar (2017), perancangan pondok Pesantren berdasarkan Al-Qur'an yang menjelaskan tentang keharusan menjaga lingkungan alam terutama manusia sebagai khalifah yang diturunkan di muka bumi. Berdasarkan sunnah rasul yang menjelaskan tentang keharusan melestarikan dan menjaga kualitas alam semesta dari kerusakan. Berdasarkan keharusan untuk mendirikan sarana pendidikan islam yang dapat merubah pola fikir dan tingkah laku individu untuk menjaga kualitas lingkungan alam dari kerusakan melalui desain arsitektur. Adapun tahapan 
desain perancangan menurut Yong (2017), di mulai dari Empathize, Define, Ideate, Prototype, serta Test. Tahapan dan metode perancangan Pondok Pesantren Raudhatul Ulum Meranti dapat dilihat pada Gambar 1 berikut.

\begin{tabular}{|c|c|c|c|c|}
\hline EMPATHIZE & DEFINE & IDEATE & PROTOTYPE & TEST \\
\hline PROSES AWAL DESAIN & PROSES ANALISA & PROSES PENGARIAN & IMPIEMENTASI IDE & PROSES EVALUASI \\
\hline $\begin{array}{l}\text { - Pengumpulan } \\
\text { data, literatur, } \\
\text { data tipologi, } \\
\text { dan data eksist- } \\
\text { ing lokasi }\end{array}$ & $\begin{array}{l}\text { - Penyusunan } \\
\text { data } \\
\text { - Analisis data } \\
\text { dan program- } \\
\text { ming }\end{array}$ & $\begin{array}{l}\text { - Penyusunan } \\
\text { konsep desain } \\
\text { - Skematik ide } \\
\text { desain dan al- } \\
\text { ternatif } \\
\text { - Pengembangan } \\
\text { skematik desain }\end{array}$ & $\begin{array}{l}\text { - Implemtasi ide } \\
\text { desain ke dalam } \\
\text { bentuk 3D } \\
\text { - Crosschek } \\
\text { dengan konsep }\end{array}$ & $\begin{array}{l}\text { - Melakukan Eval- } \\
\text { uasi } \\
\text { - Kritik desain }\end{array}$ \\
\hline
\end{tabular}

Gambar 1. Diagram Tahapan Metode Desain Perancangan

Sumber: Penulis, 2017

\section{Hasil dan Pembahasan}

\section{Lokasi Perancangan}

Perencanaan dan perancangan Pondok Pesantren Raudhatul Ulum Meranti terletak di Provinsi Kalimantan Barat, Kabupaten Kubu Raya, Kecamatan Sungai Ambawang, Desa Puguk, Jalan Muhajirin RT/RW. 01/01.

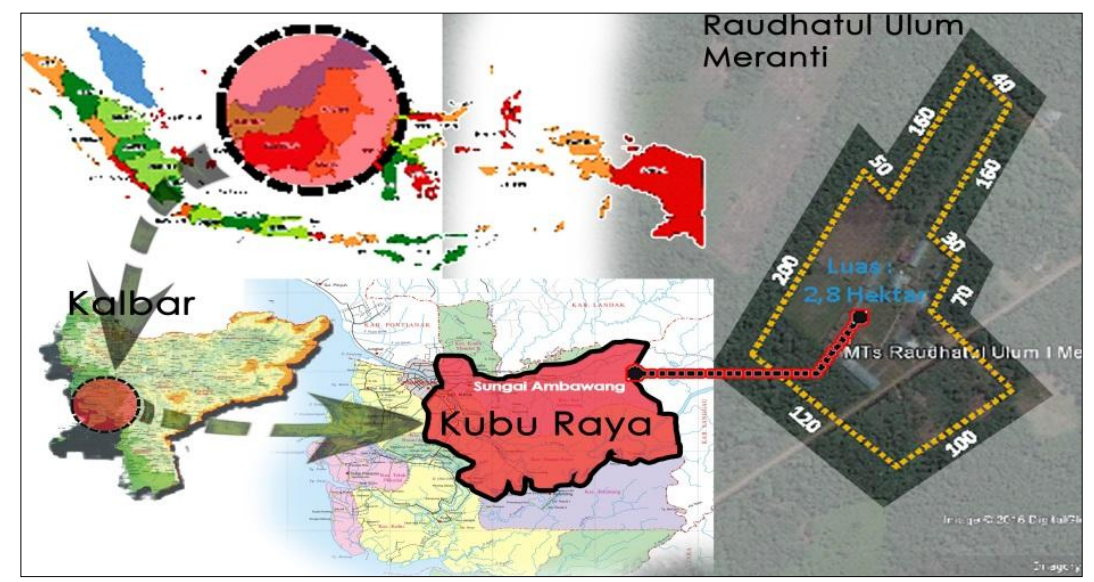

Gambar 2. Lokasi Perancangan

Sumber: Bappeda Kab. Kubu Raya (2009) Modifikasi Oleh Penulis, 2017

\section{Data Potensi dan Permasalahan Lokasi}

Lokasi perancangan terdiri dari beberapa potensi pada kawasan diantaranya: lahan masih terlihat hijau dan berupa perkebunan. Pepohonan pada area sekitar lokasi bisa dimanfaatkan sebagai material bangunan pesantren. Lokasi perancangan dekat dengan jalan utama sehingga mempermudah akses dalam tahap pembangunan. Perkebunan disekitar lokasi perancangan dapat dimanfaatkan hasil buahnya untuk menunjang kebutuhan makanan di Pesantren. Adanya bibit sawit pada Lokasi perancangan bisa dijadikan sebagai penunjang penghasilan Pesantren. Kebun pisang beserta sayursayuran pada lokasi perancangan bisa dimanfaatkan untuk dikonsumsi para santri yang tinggal di Pesantren tersebut. 


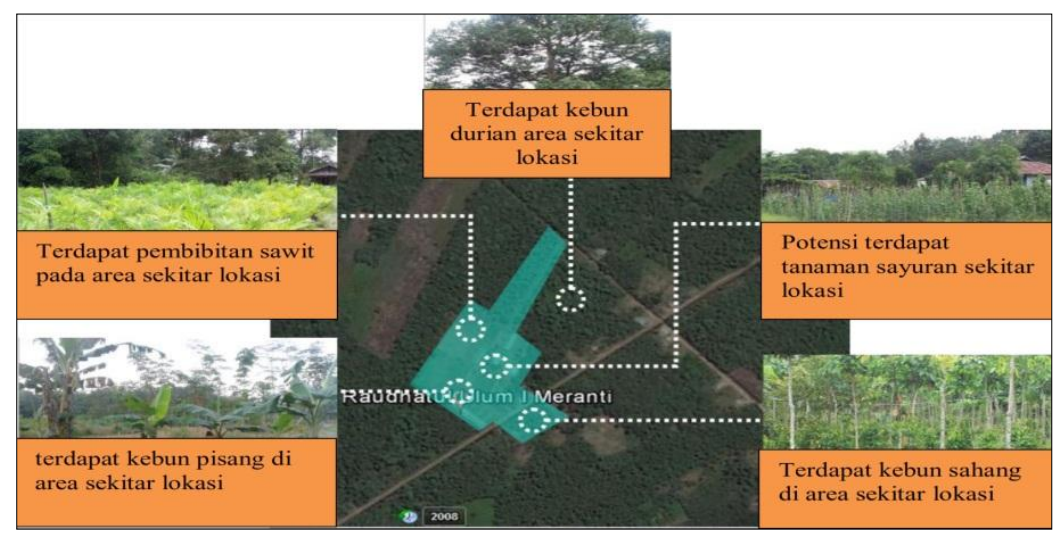

Gambar 3. Data Potensi Site

Sumber: Penulis, 2017

Lokasi perancangan juga terdapat beberapa permasalahan diantaranya: tata letak bangunan yang kurang teratur. Lahan kosong yang masih luas dan tidak dikelola dengan baik. Kondisi bangunan yang mulai rusak dan tidak terawat sehingga dapat mengganggu visual kawasan Pesantren. Kondisi drainase yang kurang baik dapat menganggu aliran arus air pada kawasan. Banyaknya sampah di area sekitar Pesantren dapat mencemari lingkungan dan menganggu kesehatan para santri. Keadaan fasilitas MCK kurang layak dikarenakan bangunan yang sudah tua dan tidak terawat.

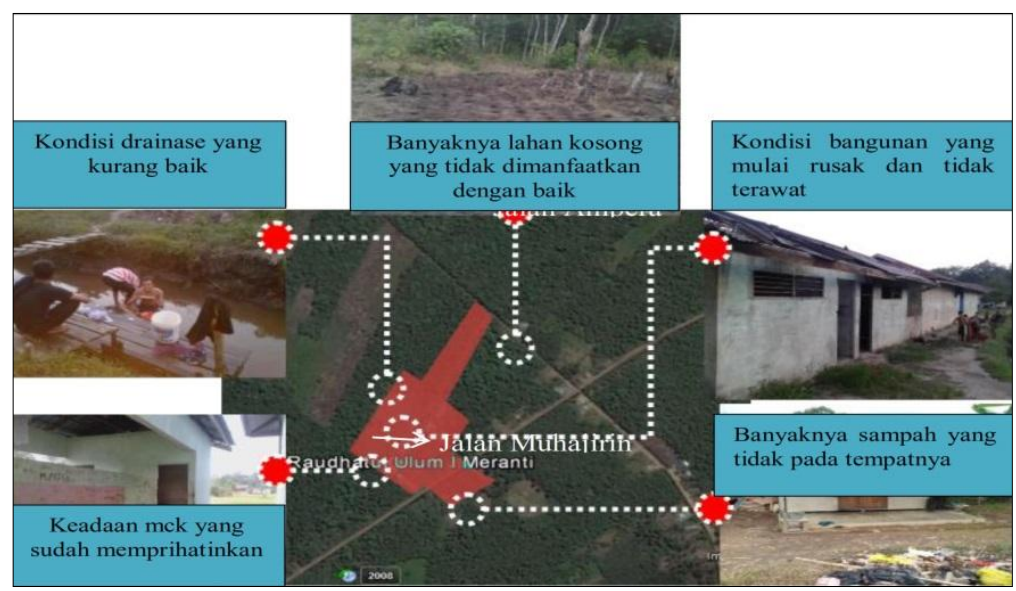

Gambar 4. Data Permasalahan Site

Sumber: Penulis, 2017

\section{Tema Perancangan}

Ide awal dari perancangan Pengembangan Kawasan Pesantren Modern Raudhatul Ulum Meranti adalah sebuah upaya untuk menciptakan kenyamanan dan keamanan pada sebuah kawasan. Kenyamanan yang dimaksud adalah membuat sebuah kawasan yang sesuai dengan penataan secara teratur, tertata serta tidak monoton. Kawasan dapat memberikan semangat dan nuansa baru bagi penghuni didalamnya. Adapun Keamanan yang dimaksud adalah menciptakan sebuah kawasan dengan batasan-batasan yang jelas baik dari penempatan zonasi, sirkulasi dan jarak pandang antara laki-laki dan perempuan.

Konsep utama dalam perancangan Pengembangan Kawasan Pesantren Modern Raudhatul Ulum Meranti didasari atas permasalahan dan potensi yang ada pada lokasi perancangan. Kawasan yang kurang tertata dengan baik, sistem pembelajaran tradisional, lingkungan yang kurang terjaga dan pola penataan lingkungan yang monoton merupakan beberapa permasalahan pada lokasi perancangan. 
Sehingga, dapat disimpulkan bahwa sangat perlunya sebuah kawasan yang tertata, segar, hijau dan tidak membosankan. Potensi pada lokasi perancangan dapat dimanfaatkan untuk menyelesaikan beberapa permasalahan yang ada. Lahan kosong pada kawasan serta banyaknya tanaman yang bisa dikonsumsi dapat dijadikan sebagai pelepas kebosanan para santri dengan cara berinteraksi langsung dengan lingkungan sekitar pesantren.

Konsep yang diusung pada Perancangan Pengembangan Kawasan Pesantren Raudhatul Ulum Meranti adalah "Natural Pro Rate". Konsep tersebut diharapkan dapat menghadirkan suasana alam pada setiap bangunan dengan cara membuat bukaan besar dan fasad bangunan yang terdiri dari unsur alam. Konsep pengembangan kawasan juga mengacu pada pola penataan kawasan yang dikombinasikan dengan unsur alam agar terciptanya sebuah perancangan yang tertata dan alami.

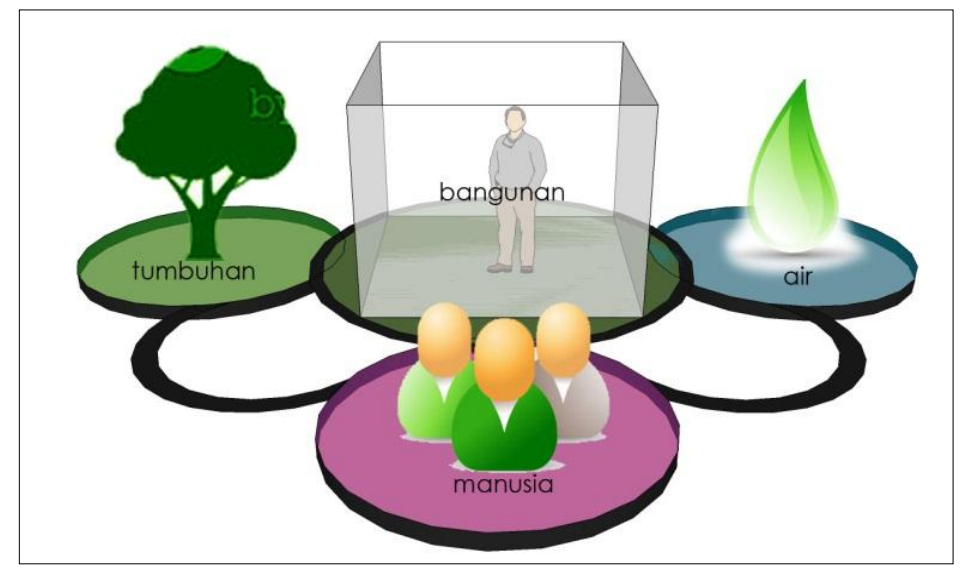

Gambar 5. Konsep Utama Perancangan

Sumber: Penulis, 2017

Alam merupakan sebuah tempat tinggal manusia yang mempunyai banyak manfaat bagi kelangsungan hidup mendatang. Konsep alam dapat memberikan kenyamanan dan ketenangan dalam bentuk memperbanyak penghijauan di sekitar kawasan. Bangunan dibuat dengan memperbanyak bukaan besar agar para santri bisa merasakan udara segar secara langsung dari luar kawasan.

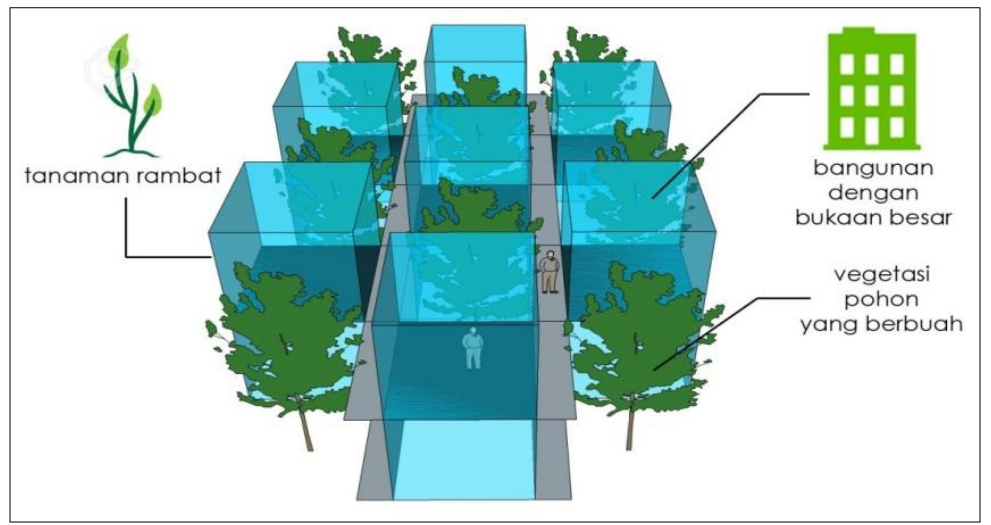

Gambar 6. Konsep Penerapan Alam pada Bangunan

Sumber: Penulis, 2017

\section{Fungsi dan Program Ruang}

Kawasan perancangan terdapat dua fungsi utama yang diperoleh berdasarkan analisis internal pada lokasi, diantaranya fungsi umum dan khusus. Fungsi umum pada lokasi perancangan terdiri atas 
fungsi kawasan, ibadah, hunian, Sekolah formal dan non formal. Fungsi khusus pada lokasi perancangan berupa fasilitas Pesantren, fasilitas ibadah, hunian santri, rumah Guru/Ustadz, penunjang perekonomian dan pengelola Pesantren.

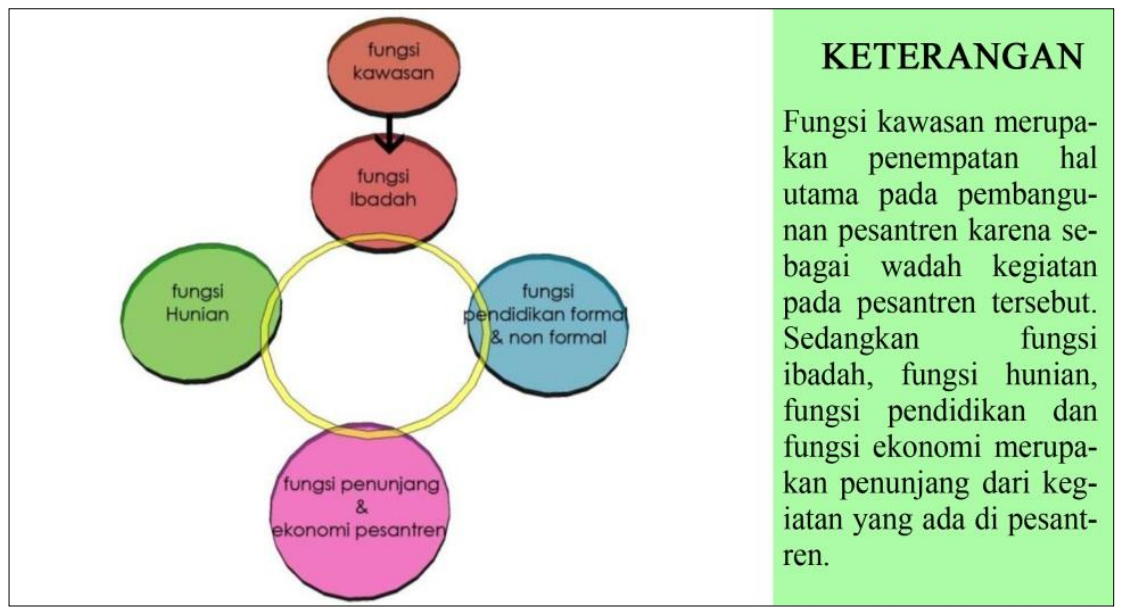

Gambar 7. Konsep Fungsi Fasilitas

Sumber: Penulis, 2017

Konsep organisasi ruang dipertimbangkan berdasarkan analisis hubungan dan fungsi ruang, agar kebutuhan sesuai dengan perencanaan. Konsep ini juga dipertimbangkan berdasarkan prinsip penerapan arsitektur Islam, agar sesuai dengan penataan fungsi yang berlandaskan Islam. Natural Pro Rate (dekat dengan alam) merupakan konsep utama dari desain pengembangan kawasan Pesantren Raudhatul Ulum Meranti. Maka dari itu, organisasi ruang yang diperoleh adalah posisi bangunan Masjid berada ditengah kawasan dan fasilitas penunjang ekonomi Pesantren diletakkan pada bagian depan kawasan. Adapun rumah Kiyai, area pendidikan, bagian informasi dan pemukiman dapat di posisikan mengelilingi Masjid.

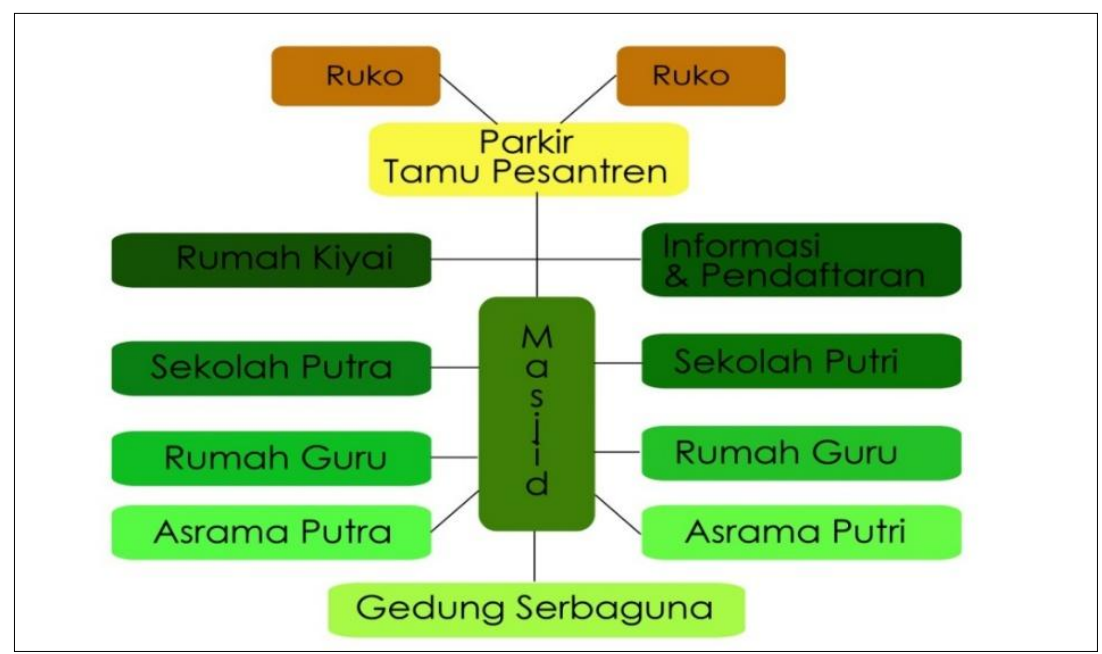

Gambar 8. Konsep Makro Organisasi Ruang Fasilitas

Sumber: Penulis, 2017

\section{Konsep Bentuk}

Bangunan pada kawasan Pondok Pesantren Raudahatul Ulum Meranti terdiri dari beberapa bentuk yang disesuaikan dengan kondisi eksisting dan lokasi perancangan. Kawasan memanjang dapat 
disesuaikan dengan bentuk bangunan yang akan di rencanakan, agar memberikan kesan seimbang pada kawasan tersebut. Bagian utama bangunan tersebut akan disusun mengikuti pola site dengan cara membuat bukaan besar pada bangunan dan penghijauan kawasan.

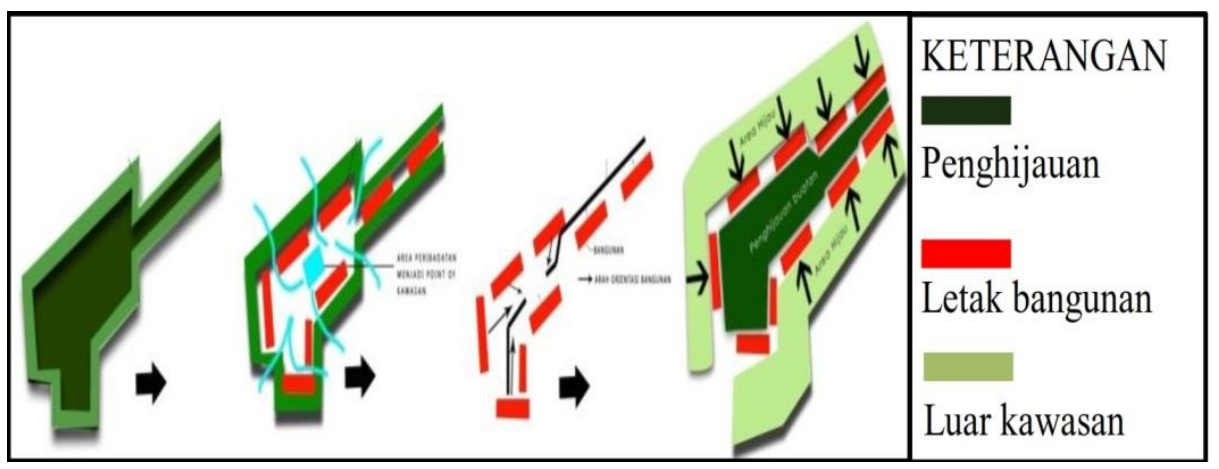

Gambar 9. Konsep Bentuk Kawasan

Sumber: Penulis, 2017

Bentuk bangunan dapat disesuaikan dengan kawasan agar menjadi sebuah perancangan yang mengutamakan fungsi ruang serta pengaruh dari luar bangunan. Adapun penerapan karakter Islami pada kawasan Pesantren, bertujuan agar ketika pengunjung memasuki kawasan Pesantren merasakan kuatnya nilai keislaman pada kawasan. Karakter utama pada lokasi perancangan yaitu menjadikan bangunan Masjid, menara kawasan, serta akses masuk yang berbeda antara laki-laki dan perempuan sebagai simbol keislaman pada kawasan tersebut.

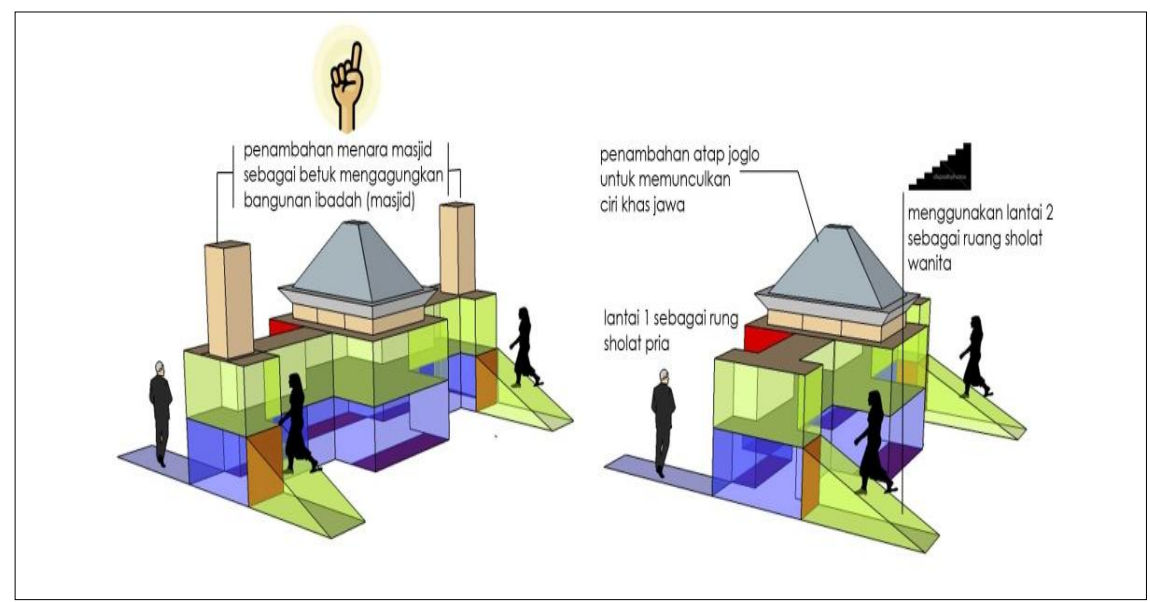

Gambar 10. Konsep Bentuk Bangunan Masjid

Sumber: Penulis, 2017

Bangunan Masjid menjadi pusat kegiatan pada kawasan Pesantren juga difungsikan sebagai pembatas (hijab) antara laki-laki dan perempuan. Kawasan yang memanjang juga menjadi landasan untuk membuat bentuk Masjid mengikuti pola site. Ornamen dan tanaman rambat menjadi karakter utama pada fasad bangunan, agar memperkuat nilai keislaman pada kawasan juga menambah kesan hijau pada bangunan. 


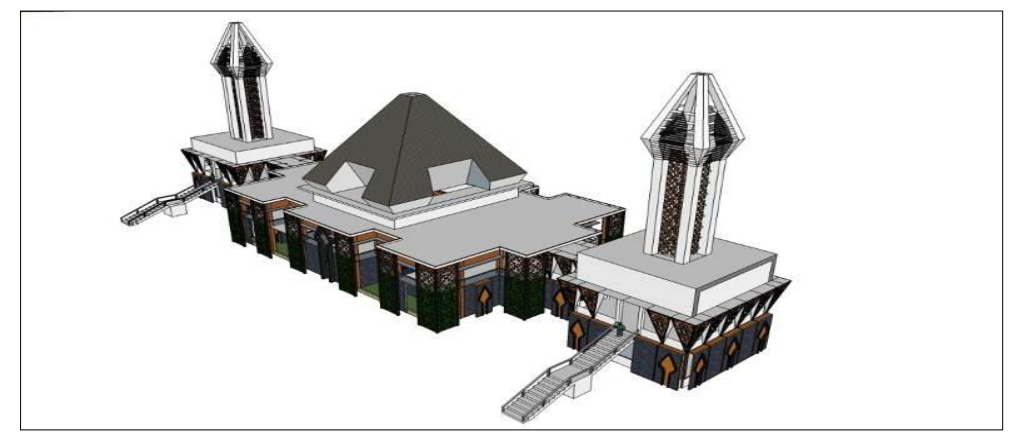

Gambar 11. Bentuk Bangunan Masjid

Sumber: Penulis, 2017

Bangunan Sekolah mengikuti struktur lama (struktur yang ada) dan disesuaikan dengan bentuk site yang memanjang. Oleh karena itu, bentuk bangunan Sekolah dibuat berdasarkan bentuk site serta menambahkan ornamen dan tanaman pada fasad bangunan agar memperkuat kesan hijau dan Islami. Bentuk atap bangunan Sekolah dikombinasikan dengan model atap Joglo untuk memperkuat nilai kebudayaan pada bangunan.

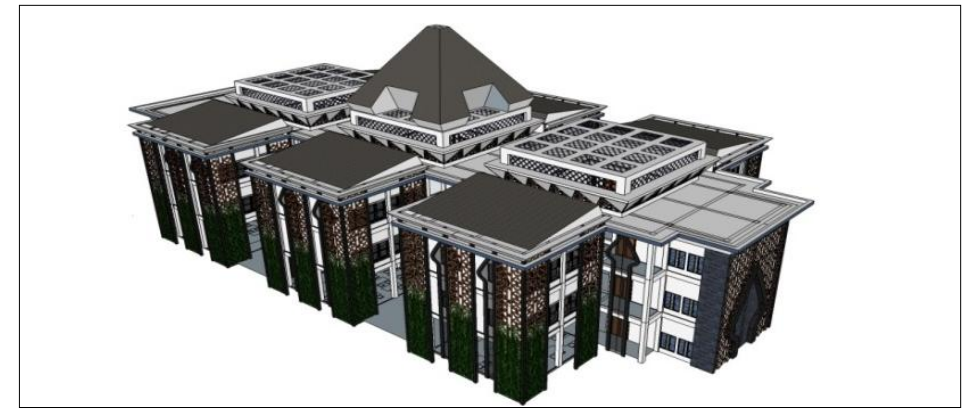

Gambar 12. Bentuk Bangunan Sekolah Sumber: Penulis, 2017

Bangunan Asrama disesuaikan dengan bentuk struktur lama (struktur yang ada) dan mengikuti pola Site. Persegi panjang merupakan bentuk penyesuaian bangunan Asrama yang sudah ada. Bentuk fasad bangunan juga dibuat berdasarkan pola memanjang vertikal, dengan cara memasukkan unsur ornamen dan penghijauan pada bagian luar bangunan untuk memperkuat konsep utama dari kawasan.

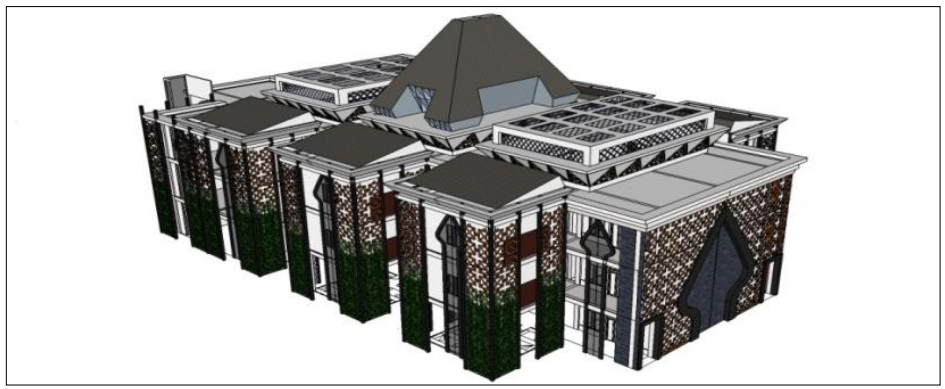

Gambar 13. Bentuk Bangunan Asrama Sumber: Penulis, 2017

Bentuk bangunan Ruko disesuaikan dengan kondisi site yang memanjang dan dibuat mengikuti site yang ada. Bangunan Ruko disusun dengan pola berselang-seling untuk mempermudah akses masuknya udara pada kawasan. Orientasi bangunan disusun saling berhadapan karena untuk menciptakan keamanan dan kemudahan akses. 


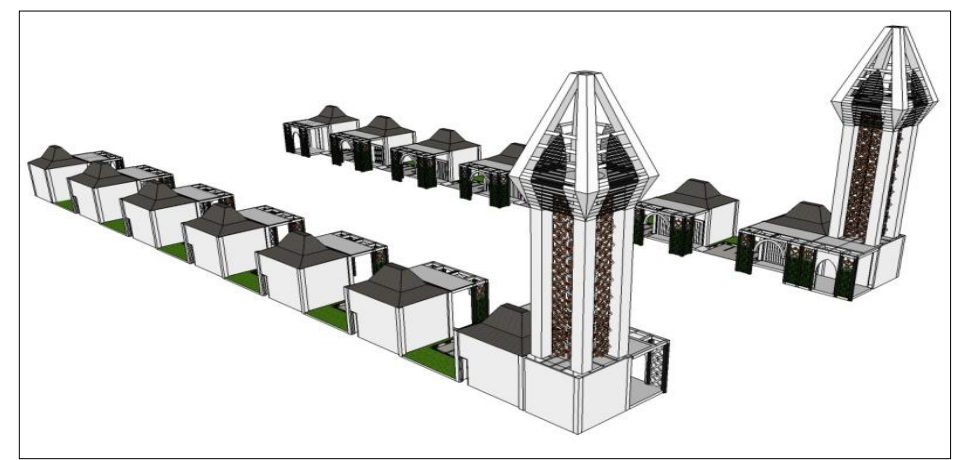

Gambar 14. Bentuk Bangunan Penyewaan

Sumber: Penulis, 2017

\section{Konsep Struktur}

Struktur bangunan pada kawasan perancangan Pesantren Raudhatul Ulum Meranti disesuaikan dengan struktur sebelumnya. Penerapan komponen struktur pada bangunan Masjid terdiri atas struktur pondasi, kolom balok dan struktur atap. Adapun komponen tersebut menggunakan tiang pancang pada struktur pondasi, kolom balok beton pada struktur tengah dan struktur atas menggunakan besi pesan.

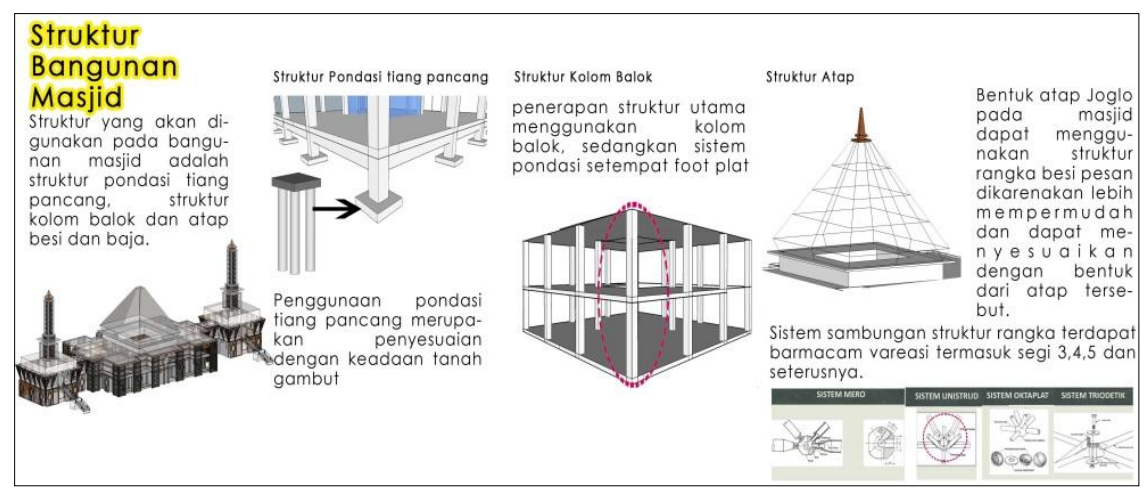

Gambar 15. Konsep Struktur Bangunan Masjid

Sumber: Penulis, 2017

Struktur bangunan Sekolah dan Asrama terdiri dari komponen struktur pondasi yang menggunakan pondasi tiang pancang. Struktur tengah menggunakan struktur kolom balok sedangkan bagian atap menggunakan struktur rangka besi. Struktur utama pada bangunan Sekolah dan Asrama harus disesuaikan dengan struktur yang ada.

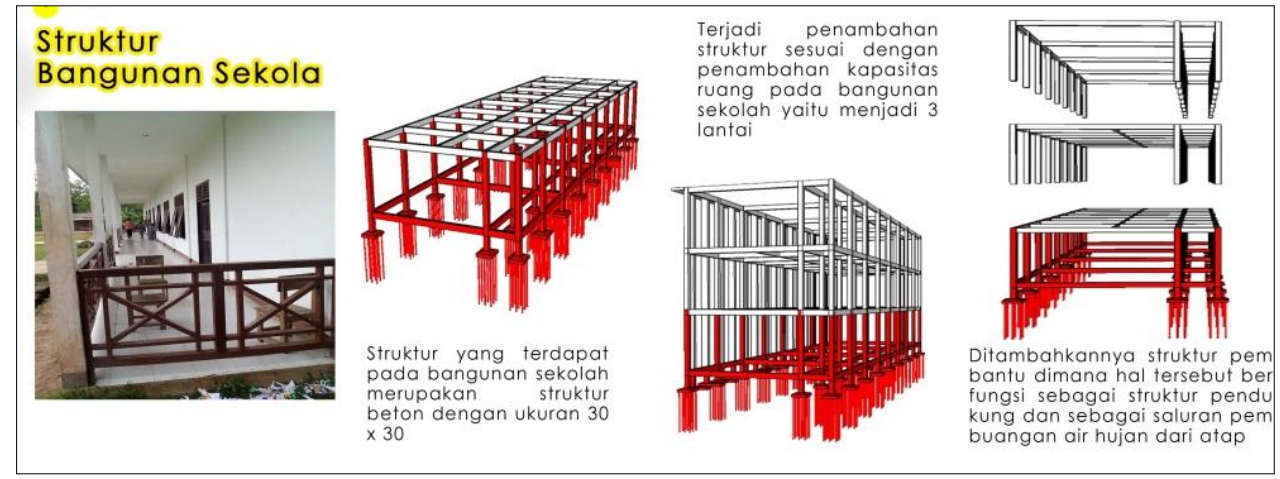

Gambar 16. Konsep Struktur Bangunan Sekolah dan Asrama Sumber: Penulis, 2017 


\section{Konsep Utilitas}

Air bersih pada kawasan Pondok Pesantren Raudhatul Ulum Meranti hanya berasal dari air hujan. Penampungan air pada kawasan dapat difungsikan sebagai penunjang kebutuhan pokok air bersih di Pesantren tersebut. Penampungan yang direncanakan berupa kolam dengan kapasitas 40x20 meter dan kedalaman 2 meter. Adapun sistem distribusi air bersih pada kawasan yaitu dari kolam dipompa pada bak penampungan dan dialirkan ke setiap bangunan di kawasan Pesantren.

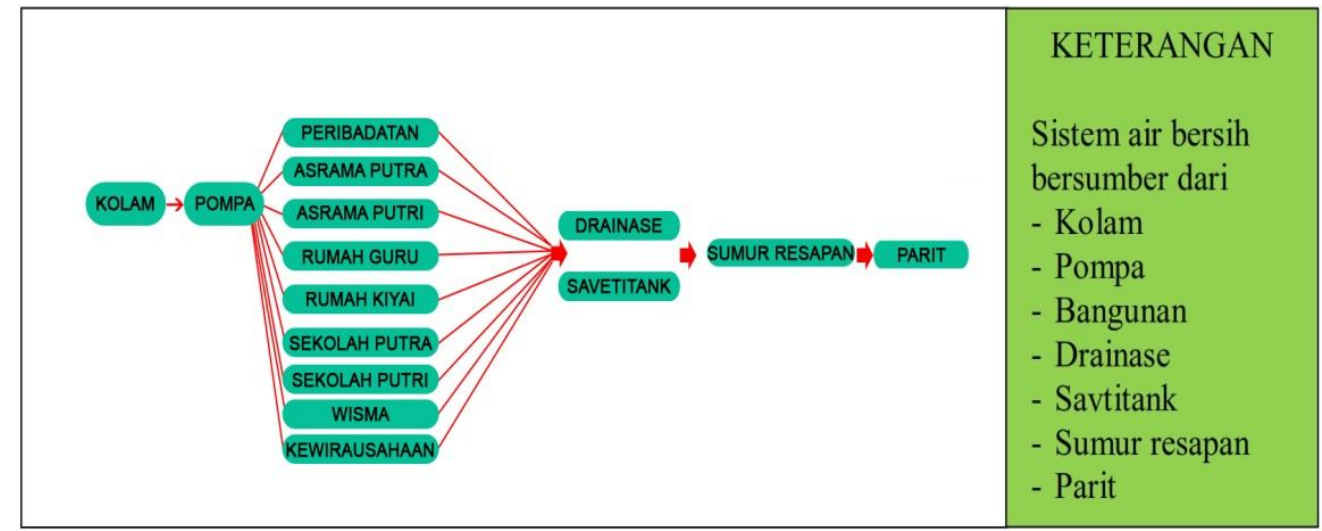

Gambar 17. Skematik Sistem Air Bersih

Sumber: Penulis, 2017

Kolam pada kawasan dapat dibuat dengan kapasitas besar agar memenuhi kebutuhan air bersih para santri, sehingga dapat membantu persediaan air bersih yang ada saat ini. Adapun sistem perairan pada kawasan ini disalurkan menggunakan sistem Down fit, di mana sistem tersebut mendistribusikan langsung pada area yang memerlukan air bersih.

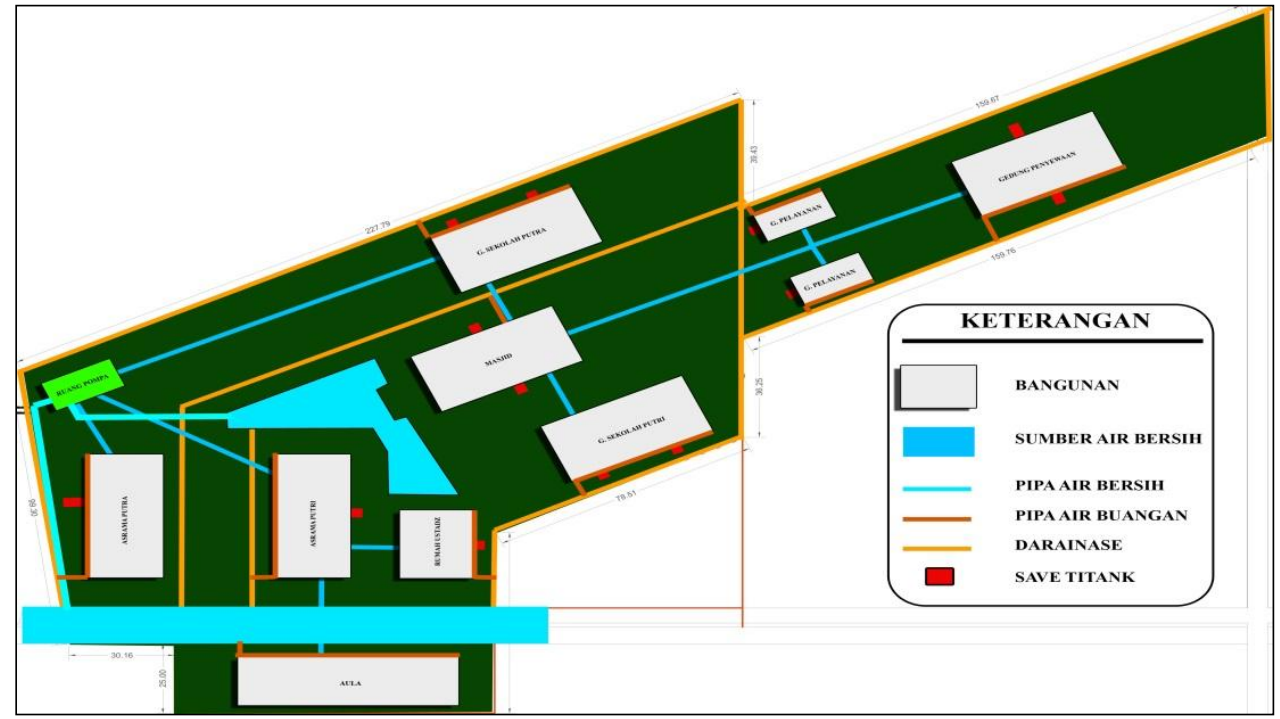

Gambar 18. Sistem Distribusi Air Bersih dan Saluran Drainase Sumber: Penulis, 2017

Tenaga listrik yang tersedia (PLN) dapat dimanfaatkan dengan cara penggunaan daya berdasarkan kebutuhan listrik yang diperlukan pada kawasan. Perlunya sistem cadangan listrik sementara (genset/mesin pembangkit listrik) karena dikhawatirkan terjadinya gangguan atau pemadaman pada kawasan Pesantren. 


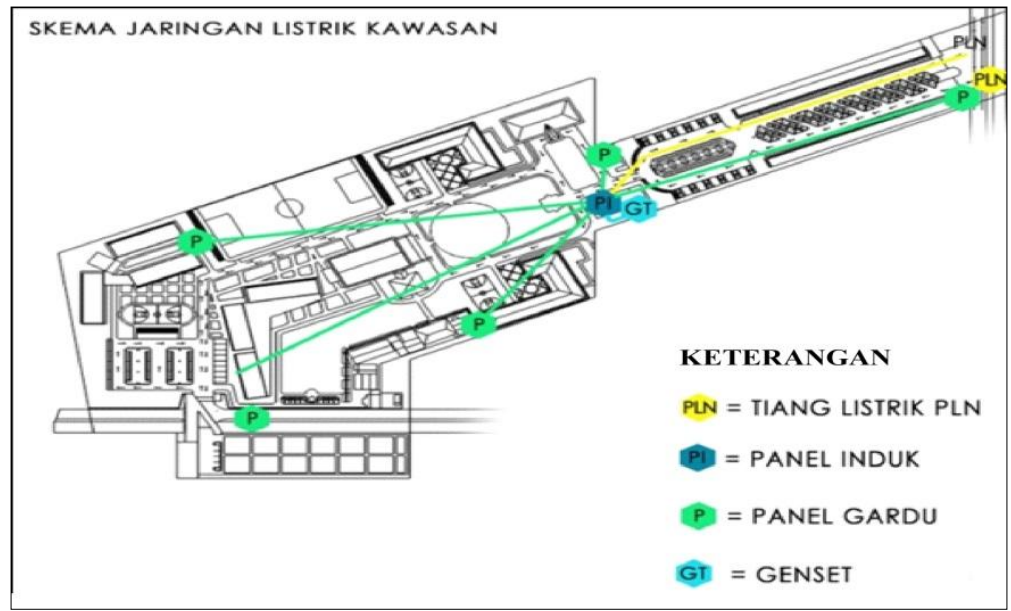

Gambar 19. Skematik Sistem Kelistrikan

Sumber: Penulis, 2017

\section{Hasil Perancangan}

Perancangan Pengembangan Kawasan Pesantren Raudhatul Ulum Meranti merupakan sebuah rancangan yang mengacu pada pembangunan terdahulu. Kawasan Pesantren terbagi ke dalam beberapa masa bangunan diantaranya: Masjid, Sekolah, Asrama, pusat pelayanan/administrasi, rumah Guru/Ustadz, rumah Kiyai dan bangunan penunjang ekonomi Pesantren. Jalur akses masuk kawasan terbagi menjadi dua akses yaitu pintu masuk utama difungsikan sebagai pintu masuk umum dikarenakan dekat dengan jalan utama, sedangkan pintu masuk kedua dijadikan sebagai akses pengelola servis dan dibuka ketika ada acara tertentu.

Jalur umum yang merupakan zona publik di posisikan pada bagian depan kawasan diantaranya bangunan fasilitas penunjang ekonomi, area parkir dan gedung informasi. Zona semi privat di posisikan pada bagian tengah kawasan dan dijadikan pembatas (hijab) antara laki-laki dan perempuan. Area tersebut terdiri dari bangunan Masjid, rumah Guru/Ustadz dan rumah Kiyai. Zona privat diposisikan pada bagian tepi kawasan dibuat akses terpisah antara laki-laki dan perempuan.

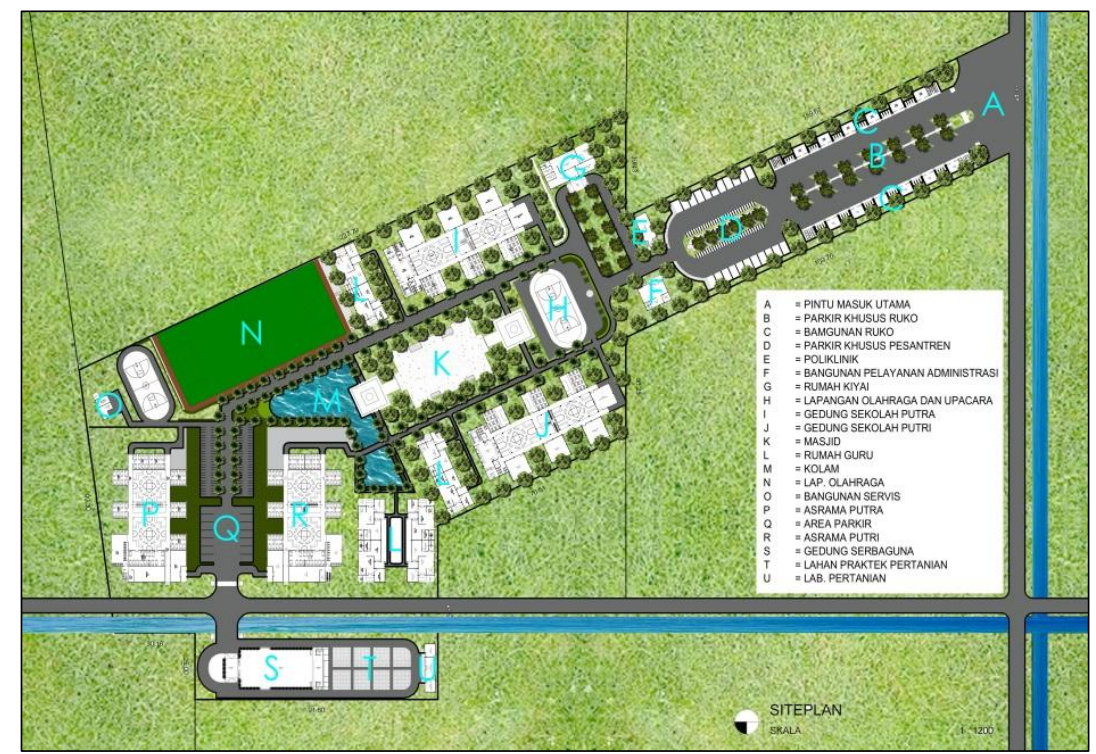

Gambar 20. Site Plan Hasil Perancangan

Sumber: Penulis, 2017 
Natural Pro Rate diterapkan dengan cara membuat bukaan besar pada bangunan. Tanaman rambat yang ada pada kawasan dapat difungsikan sebagai bagian dari fasad bangunan agar terkesan hijau. Ornamen Islam dibuat pada bagian fasad bangunan untuk menjadikan kesan Islami pada kawasan. Kolam pada kawasan dibuat agar lingkungan terkesan sejuk dan penanaman vegetasi juga memberikan kesan hijau, sehingga dapat menciptakan ketenangan pada santri.

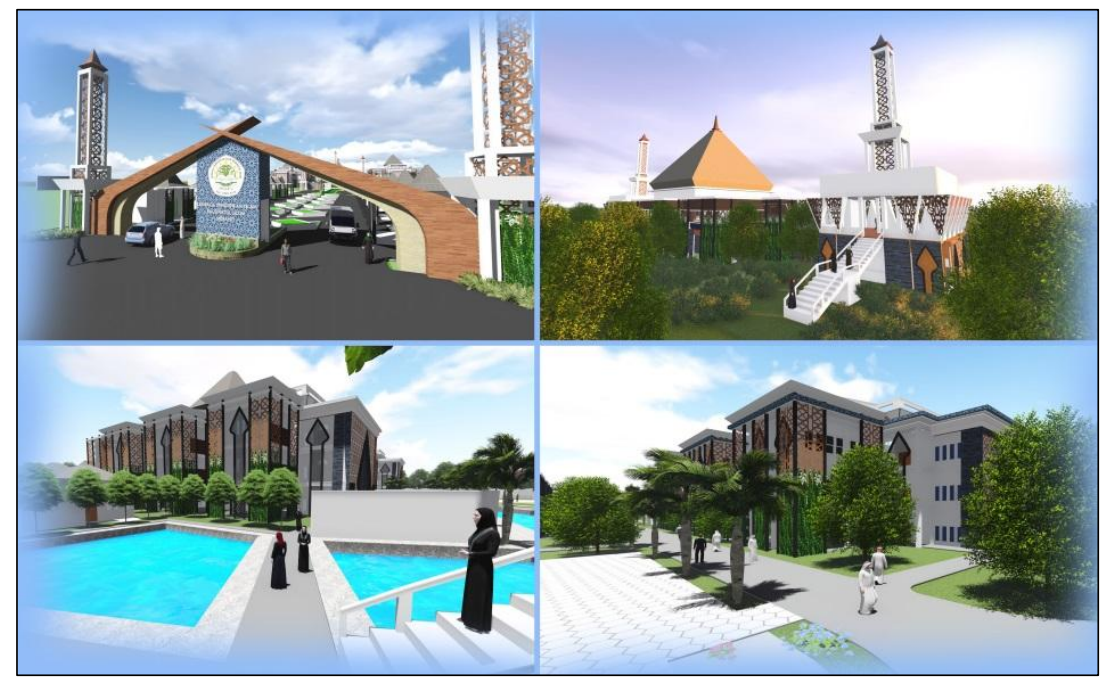

Gambar 21. Suasana Eksterior Bangunan Sekolah, Asrama dan Masjid Sumber: Penulis, 2017

Taman Indoor juga merupakan terjemahan dari konsep Natural Pro Rate (dekat dengan alam), tujuannya adalah menciptakan ruang terbuka hijau pada area luar dan dalam bangunan. Fungsi tersebut juga sebagai tempat santai, tempat belajar bersama, interaksi para santri, pelepas kebosanan dan menjadi nilai estetika pada bangunan. Taman dibuat agar dapat dilihat secara langsung dari luar maupun dalam, serta dapat dinikmati dari lantai atas dengan adanya bukaan besar pada bangunan.

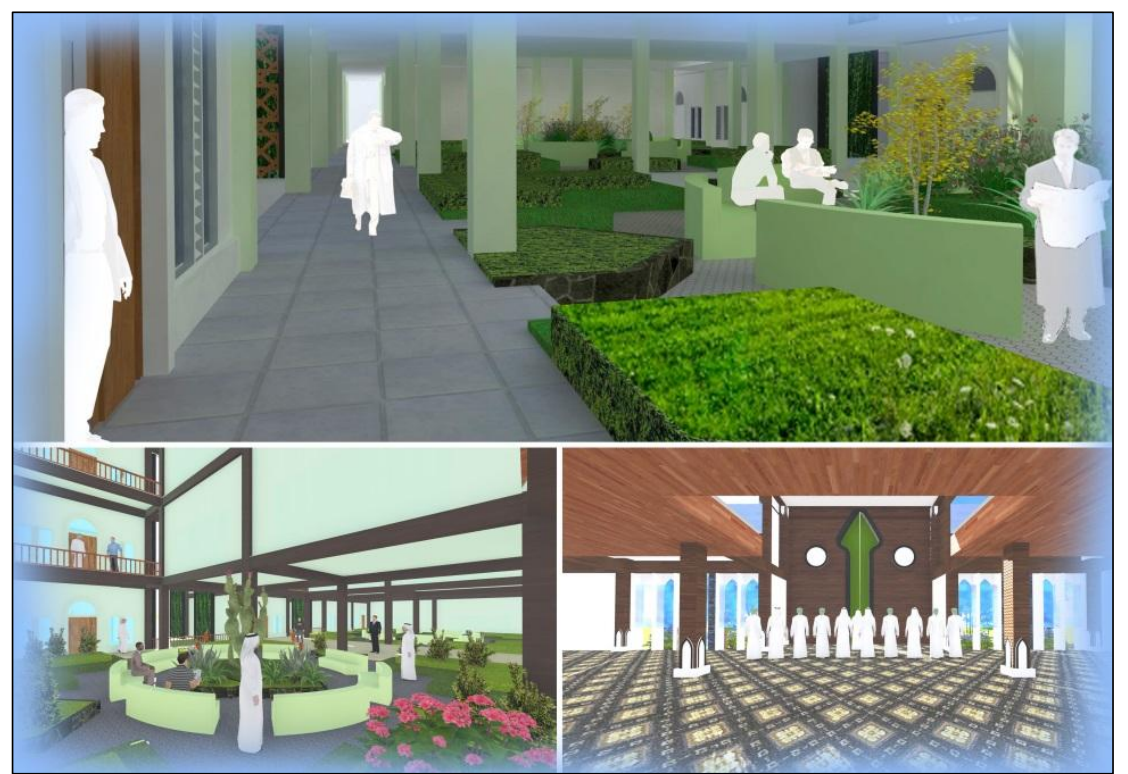

Gambar 22. Suasana Taman Indoor pada Asrama, Sekolah dan Masjid Sumber: Penulis, 2017 


\section{Kesimpulan}

Perancangan Pengembangan Kawasan Pesantren Raudhatul Ulum Meranti didasari akan perlunya sebuah pengembangan kawasan yang memfokuskan pada penambahan fasilitas Pesantren. Perancangan kawasan yang mengacu pada konsep Natural Pro Rate (dekat dengan alam), yang merupakan gagasan utama dalam menghasilkan sebuah perancangan untuk memberikan kenyamanan bagi santri bermukim. Memperbanyak bukaan pada bangunan merupakan suatu bentuk desain yang tidak membatasi jarak pandang para santri, sehingga santri bisa langsung menikmati alam sekitar. Memperbanyak vegetasi pada kawasan di luar maupun dalam bangunan agar menghasilkan udara yang sehat dan hijau. Menghadirkan taman indoor agar memberikan suasana sejuk pada bangunan. Penerapan unsur Arsitektur Islam pada perancangan menjadi poin utama dalam menentukan zona kawasan. Bangunan Masjid di posisikan pada bagian tengah kawasan, agar menjadi sebuah simbol bangunan Islami dan menjadi pemisah antara laki-laki dan perempuan (hijab). Membuat enam menara pada kawasan sebagai bentuk terjemahan dari rukun iman pada agama Islam dan menjadikan menara sebagai simbol Islami yang dapat dipandang dari kejauhan.

\section{Ucapan Terima Kasih}

Terima kasih kepada Bapak Dr. techn. Zairin Zain, S.T, M.T.; Bapak Hamdil Khaliesh, S.T, M.T.; Bapak M. Ridha Alhamdhani, S.T. M.Sc. dan Bapak Jawas Dwijo Putro S.T., M.Sc. selaku dosen pembimbing di Program Studi Arsitektur, Fakultas Teknik, Universitas Tanjungpura, yang telah banyak memberikan bimbingan, saran, serta motivasi kepada penulis. Bapak Badrut Tamam Rusdi S.Pd.I.,M.Pd.I sebagai pihak ketiga. Kepada rekan arsitek angkatan 2013 yang terlibat dalam Proyek Tugas Akhir ini penulis mengucapkan terima kasih yang sebesar-besarnya.

\section{Daftar Acuan}

Ariandy, Desti, E. (2011). Pondok Pesantren di Yogyakarta. Jakarta: LPEES

Bappeda Kabupaten Kubu Raya. (2009). Rencana Tata Ruang Wilayah Kabupaten Kubu Raya Tahun 2009-2029. Kubu Raya: Bappeda Kabupaten Kubu Raya

Dhofier, Z. (1994). Tradisi Pesantren Studi Tentang Pandangan Hidup Kyai. Yogyakarta: Universitas Ahmad Dahlan

Dzulfikar, F. (2017). Perancangan Pondok Pesantren di Madrasah Tsanawiyah Negeri Malang Turen. Malang: Universitas Islam Negeri Maulana Malik Ibrahim

Mastuhu. (1994). Dinamika Sistem Pendidikan Pesantren. Jakarta: Institut Negeri Islam (INIS)

Mas'ud, A. (2002). Dinamika Pesantren dan Madrasah. Yokyakarta: Pustaka Belajar

Nawawi. (2006). Sejarah dan Perkembangan Pesantren. Purwekerto: Jurnal Studi Islam dan Budaya Vol.4 No. 1 Hlm $4-$ 19. P3M STAIN

Rusdi, B.T. (2017, March 20). Lembaga Pendidikan Islam Raudhatul Ulum Meranti. [Personal Interiew]

Setyowati, N.H. (2010). Pondok Pesantren Modern berwawasan lingkungan di Semarang. Semarang: Universitas Diponegoro

Yong, S.D. (2017). Silabus Desain Interior \& Styling 2. Surabaya: Universitas Kristen Petra

Ziemek, M. (1983). Pesantren dalam Perubahan Sosial. Jakarta: P3M 